\title{
Promoting Physical Activity AmongAdolescents: Recommendations From Correlation Research La promoción de la actividad físicas entre los adolescentes: recomendaciones a partir de la investigación correlacional \\ Paula Louise Bush* \& Cathy MacDonald** \\ *McGill University; Montreal, Quebec (Canada), **State University of New York at Cortland, Cortland, New York (USA)
}

\begin{abstract}
Adolescents are not meeting physical activity (PA) guidelines for health and, although there has been much PA intervention research for this age group, most studies have had only a small effect on teens' PA. Many have observed that teenagers' PA is determined by a complex array of intrapersonal, interpersonal, and family, school, and community environmental factors. We sought to update previous reviews of correlates of adolescent PA, focusing exclusively on modifiable correlates of adolescents' PA to suggest avenues for PA promotion intervention design. Based on our findings from twenty studies exploring correlates among international samples of adolescents, we suggest that parent and peer PA and support of adolescents' PA are important influencing factors to consider when designing PA promotion interventions for teenagers. Moreover, limited work suggests the potential importance of physical environment modifications.
\end{abstract}

Keywords. physical activity, adolescent correlates, review.

Resumen. Los adolescentes no están cumpliendo con las recomendaciones de actividad física (AF) para la salud y, aunque ha habido mucha investigación en la intervención de AF para este grupo de edad, la mayoría de los estudios han tenido sólo un pequeño efecto sobre la AF de los adolescentes. Muchos han observado que la AF de los adolescentes está determinada por una compleja serie de factores intrapersonales, interpersonales, del contexto familiar y escolar y de la comunidad. Hemos tratado de actualizar las revisiones previas de los correlatos de la AF en los adolescentes, centrándonos exclusivamente en los correlatos modificables de AF de los adolescentes para sugerir ideas en el diseño de intervenciones de promoción de la AF. En base a los resultados de veinte estudios que exploraron las correlaciones entre muestras internacionales de adolescentes, se sugiere que la AF de los padres y los compañeros y el apoyo de ambos a la AF de los adolescentes son factores de influencia importantes a considerar en el diseño de intervenciones de promoción de la AF para los adolescentes. Por otra parte, algunas investigaciones sugieren la importancia potencial de modificaciones en el entorno físico.

Palabras clave. actividad fisica, adolescentes, correlatos, revision.

\section{Introduction}

Worldwide, adolescents are not meeting physical activity (PA) guidelines for health (Colley et al., 2012; Ekelund, Tomkinson, \& Armstrong, 2011; National Institute for Health and Care Excellence, 2009; World Health Organization, 2004). Although there has been much PAintervention research for this age group, most studies have had only a small effect on teens' PA, in particular their PA outside of school (de Meester, van Lenthe, Spittaels, Lien, \& De Bourdeaudhuij, 2009; Dobbins, De Corby, Robeson, Husson, \& Tirilis, 2009). Notably, a systematic review of 24 school and non-school based PA Randomized controlled trials found that while there was no conclusive evidence of an effect on teen PAfor programs restricted to the school setting, there was strong evidence of an effect for those involving the family or community (van Sluijs, McMinn, \& Griffin, 2008). Similarly, the European adolescent PApromotion literature indicates multi-component programs extending beyond the school setting have generally resulted in larger effect sizes than those focused exclusively on the school (Crutzen, 2010).

The precise reasons for this are, as yet, unknown, but many have observed that teenagers' PA is determined by a complex array of intrapersonal, interpersonal, and family, school, and community environmental factors (Ommundsen, Klasson-Heggebo, \& Anderssen, 2006; Sterdt, Liersch, \& Walter, 2014). To design and implement PA promotion interventions susceptible to increase adolescents' participation in PA, developing an understanding of modifiable correlates of their PA is warranted. Literature reviews, including three reviews of reviews, have explored the issue. With respect to themodifiable correlates of adolescents' PA examined, two reviews of reviews note consistent positive associations for parental support, and varied associations for peer and other family influences and opportunities to exercise (Biddle, Atkin, Cavill, \& Foster, 2011; Sterdt, Liersch, \& Walter, 2014), while a third found that parent PA appears to be more important in childhood than adolescence, but that no conclusive result was present for the relation between parental support and youths' PA(de Vet, de Ridder, \&

Fecha recepción: 30-09-14- Fecha envío revisores: 30-09-14- Fecha de aceptación: 15-11-14 Paula Louise Bush

paula.bush@mcgill.ca de Wit, 2011). Taken together, results regarding these social influences of adolescent PA are equivocal. Among the extant reviews themselves, most included studies published in or before 2005 (Ferreira et al., 2007; Pugliese \& Tinsley, 2007; Sallis, Prochaska, \& Taylor, 2000; Van der Horst, Paw, Twisk, \& Van Mechelen, 2007). Edwardson and Gorely (2010) included studies published up to and including 2009, but focused exclusively on parental influences of teens' PA. Thus, an updated synthesis of our knowledge of correlates of teens' PA is, at this point, appropriate. Herein, we focus on modifiable correlates of PA of adolescents in the grades 7 through 12 age range, with the hope that this review suggests avenues for adolescent PA promotion program design.

\section{Methods}

\section{Information sources and literature search}

To identify potentially relevant articles about adolescent physical activity correlational research, a combination of subject headings and keywords were used in SPORTDiscus, ISI Web of Knowledge, Scopus, PsychINFO, Medline, and Health and Psychosocial Instruments (HaPI). Databases were searched up to October $10^{\text {th }}$, 2014. Specific search strategies for each database can be obtained from the authors.

\section{Identification and selection processes}

Through an iterative process of criteria development, testing, and modification we developed identification and selection tools. Our main inclusion criterion of interest concerned correlates of PA: we only included studies that examined modifiable correlates of adolescent PA. Also, we chose to exclude studies assessing only intrapersonal correlates of PA, such as behavioural or cognitive correlates, given that most PA promotion intervention research has focussed on intrapersonal influences of PA (Bush, 2014), and multiple reviews of the intervention research underscore the importance of designing interventions that go beyond this level of influence (de Meester, van Lenthe, Spittaels et al., 2009; Dobbins, De Corby, Robeson et al., 2009; Perry, Garside, Morones, \& Hayman, 2012). Table 1 presents our 5 identification and 6 selection criteria.

We each independently read titles and abstracts to identify potentially relevant articles, coding each identification criterion as ' 1 ' for 'yes', ' 0 ', for 'no', and ' 2 ' for 'unsure'. To determine agreement regarding studies to move to selection phase, we met to discuss divergent codes. When 


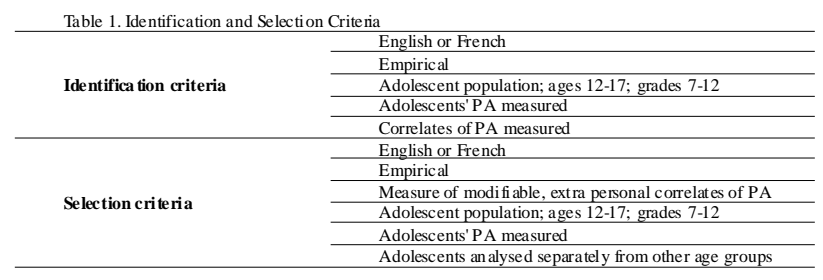

we disagreed, discussions pertained to the codes, more so than the abstracts. We then read the selected full text papers, coding the selection criteria and retaining papers or discussing and resolving disagreements in the same manner as for the identification phase.

\section{Data collection}

We extracted data pertaining to two aspects from each included study: (a) descriptive data about the study, and (b) results regarding modifiable correlates of physical activity (e.g., parental encouragement, opportunities for PA). All extracted data were entered into one excel spreadsheet. We did not extract data regarding PA behaviour correlates (e.g. participation in organised sports) because most included studies are cross-sectional and thus do not indicate the direction of the relationship between PA behaviour correlates and overall PA; a positive association may be indicative of the fact that physically active youth engage in sports. Given our objective is to identify modifiable correlates that may be addressed by programs or interventions that seek to promote PA to less active teenagers, it was logical to focus on correlates outside of the individual.

\section{Synthesis}

Using an ecological framework to guide our analysis, we categorised modifiable correlates according to social (school, home, community) and physical environment (school home, community) domains.

\section{Results}

We identified 785 unique records from the literature and selected 108 potentially relevant full-text papers. At the end of the selection phase, we retained 20 articles for inclusion in this review. As per the PRISMA flow diagram (Figure 1), inter-rater agreement for both identification and selection phases was moderate (Landis \& Koch, 1977).

\section{Description of included studies}

Table 2 represents descriptive data for all included studies. Seven of the studies included 12-13 year old participants, nine studies included 14-19 year olds, and six addressed both age groups. Sample sizes ranged from 100-5250. A cross-sectional design was used in all studies except one (Viira \& Raudsepp, 2003) and eleven of the studies were conducted outside North America (Deforche, Van Dyck, Verloigne, \& De

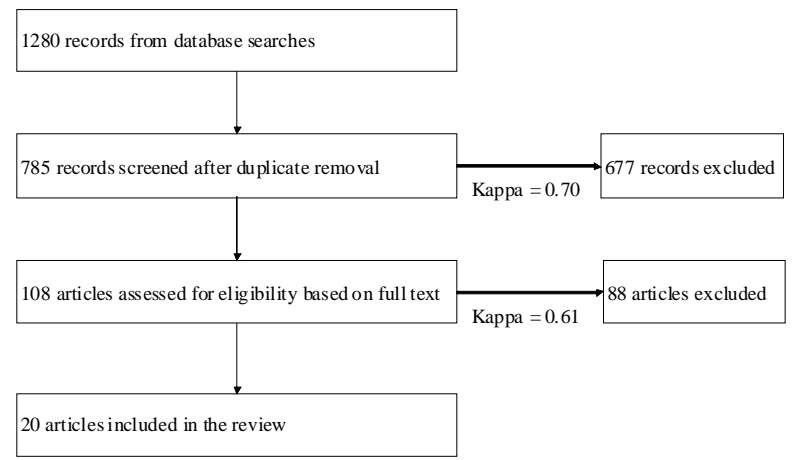

Figure 1. PRISMA Flow Diagram

Adapted from: Moher D, Liberati A, Tetzlaff J, Altm an DG, and The PRIS MA Group (2009)
Bourdeaudhuij, 2010; Haug, Torsheim, \& Samdal, 2008; Kim \& Cardinal, 2010; Kok Sonk, Loprinzi, \& Trost, 2010; Loucaides, 2009; McMinn, van Sluijs, Wedderkopp, Froberg, \& Griffin, 2008; Ommundsen, Klasson-Heggebo, \& Anderssen, 2006; Raudsepp \& Viira, 2000; Shokrvash et al., 2013; Viira \& Raudsepp, 2003; Wu, Pender, \& Noureddine, 2003). Only three studies (McMinn, van Sluijs, Wedderkopp et al., 2008; Sallis, Prochaska, Taylor, Hill, \& Geraci, 1999; Young, D. et al., 2014) assessed physical activity objectively using accelerometers; all others used various self-report measures(Table 1). All studies examined correlates for boys and girls, except for three that looked only at girls (Bungum, Pate, Dowda, \& Vincent, 1999; Ward et al., 2006; Young, D., Saksvig, Wu et al., 2014) and one that focussed on boys (Deforche, Van Dyck, Verloigne et al., 2010). Herein, we describe results according to social and physical environmental influences on teenagers' PA. As sex differences in physical activity and its related psychosocial factors have been documented in previous studies (Beets, Vogel, Forlaw, Pitetti, \& Cardinal, 2006) where possible, we describe results according to boys and girls separately.

\section{Social environment}

In their extensive review, Fitzgerald, Fitzgerald, and Aherne (2012) found that peers and friends play an important role for youths' physical activity among 10 to 18 year olds, and this holds true for the twelve (out of 23) studies included in this review that focussed on adolescents. The following discussion complements this previous review as it examines teenagers exclusively, is more inclusive with respect to nationality of participants, and is based on a literature search that extended four years beyond that of Fitzgerald, Fitzgerald, and Aherne (2012).

Spink etal. (2006) examined correlates for participation in structured and unstructured activity and therefore used data only from teens who were considered sufficiently active (i.e., reporting energy expenditure of $8 \mathrm{kcal} \cdot \mathrm{kg}^{-1}$. day $^{-1}$ or greater and engaged in both types of activities). Similar to Cypriot and Norwegian studies (Loucaides, 2009; Ommundsen, Klasson-Heggebo, \& Anderssen, 2006), the authors note that among older teens, friends' PA and support were identified as correlates of PA by 55\% of participants (although the association was greater for unstructured PA compared to structured PA). Moreover, in a Belgian sample of 17 year old boys, Deforche, Van Dyck, Verloigne et al. (2010) found that friends' PA was positively associated with boys' leisure time sports and an Estonian sample of 13 year old boys revealed that friends' attitude for PA was associated with PA(Viira \& Raudsepp, 2003). These results are corroborated by study that used accelerometer PA data (Sallis, Taylor, Dowda, Freedson, \& Pate, 2002). Likewise, among 8th grade girls, positive associations between PA and friends' support or friends attitude have been found (Raudsepp \& Viira, 2000; Viira \& Raudsepp, 2003; Young, D., Saksvig, Wu et al., 2014) and among 11th grade girls' moderate- vigorous PA was associated with positive support from boys (Young, D., Saksvig, Wu et al., 2014). It is noteworthy, that in our sample, one study found no association between peer support and PA of Danish teens 14-16 years old (McMinn, van Sluijs, Wedderkopp et al., 2008). Differences in findings could be due to measurement error and limitations inherent in measuring PA among adolescents.

As with all cross sectional studies, the directions of these associations are unknown. However, those who have done path analyses found there is both a direct (Wu, Pender, \& Noureddine, 2003) and indirect (Sabiston \& Crocker, 2008; Silva, Lott, Wickrama, Mota, \& Welk, 2012; Wu, Pender, \& Noureddine, 2003) path from peer influences (social support, modelling \& norms) to teenage boys' and girls' PA.

With respect to parents' support, examining studies published prior to 2000, Sallis, Prochaska, and Taylor (2000) found parental support, direct help from parents, and support from significant others were consistently related to adolescent physical activity as was sibling physical activity. Yet, more recent work suggests a less certain relationship.ADanish study found no association with PA and parental support among older teens (McMinn, van Sluijs, Wedderkopp et al., 2008). Whereas, Spink, Shields, Chad et al. (2006) found that $40 \%$ of 


\begin{tabular}{|c|c|c|c|c|}
\hline Authors (year) & Sample & Country & PA measure & Main results \\
\hline $\begin{array}{l}\text { Bungum et al. } \\
\text { (1999) }\end{array}$ & $\begin{array}{l}\text { Girls; 14-18; African } \\
\text { American \& Caucasian }\end{array}$ & USA & $\begin{array}{l}\text { A modification of the Stanford } \\
\text { Physical Activity Recall (PAR) }\end{array}$ & Family support was significant for African American girls' MPA \\
\hline $\begin{array}{l}\text { Sallis et al. } \\
(1999)\end{array}$ & $\begin{array}{l}\text { Boys \& girls in grades } 7-9 \\
\& \text { grades } 10-12\end{array}$ & USA & $\begin{array}{l}\text { An } 11 \text {-item global child physical } \\
\text { activity index created from } \\
\text { parent- \& child-reports }\end{array}$ & $\begin{array}{l}\text { Family support was significant for PA of boys and girls in grades 7-9 \& 10- } \\
12\end{array}$ \\
\hline $\begin{array}{l}\text { Raudsepp \& } \\
\text { Viira (2000) }\end{array}$ & $\begin{array}{l}\text { Boys and girls; } 13 \text { to } 15 \\
\text { years old (mean=14.2) }\end{array}$ & Estonia & 7DPAR & $\begin{array}{l}\text { Father's \& best friend's PA significant for PA of boys and girls. Mother's PA } \\
\text { significant for very hard PA of girls }\end{array}$ \\
\hline $\begin{array}{l}\text { McGuire et al. } \\
\text { (2002) }\end{array}$ & $\begin{array}{l}\text { Boys \& girls; junior \& } \\
\text { senior high schools }\end{array}$ & USA & $\begin{array}{l}\text { Modified version of the Godin \& } \\
\text { Shephard Leisure Time Exercise } \\
\text { Questionnaire }\end{array}$ & $\begin{array}{l}\text { Strong relationship between parents' encouragement for PA and boys' PA } \\
\text { among Caucasian and African Americ an boys, compared to Asian, Hispanic, } \\
\text { and other race/ethnicity groups. Parents' encourag ement for physical activity } \\
\text { positively correlated to girls' PA. No relationships between parents' PA and } \\
\text { teens' PA. }\end{array}$ \\
\hline $\begin{array}{l}\text { Sallis et al. } \\
(2002)\end{array}$ & $\begin{array}{l}\text { Boys and girls; grades } 7-9 \\
\& 10-12\end{array}$ & USA & $\begin{array}{l}\text { Accelerometer \& PA } \\
\text { questionnaire designed for the } \\
\text { study, self \& parent report }\end{array}$ & $\begin{array}{l}\text { Based on questionnaire data, peer support significant for PA of boys and } \\
\text { girls in grades 7-9; Family support significant for PA of girls in grades 10- } \\
12 \text {; Based on accelerometer data, peer PA and support significant for PA of } \\
\text { boys in grades 10-12 and girls in grades 7-9. }\end{array}$ \\
\hline Wu et al. (2003) & $\begin{array}{l}\text { Boys \& girls; } 12-15 \text { years } \\
\text { old (mean=13.5 } \pm 0.7 \text { ) }\end{array}$ & Taiwan & $\begin{array}{l}\text { Child/Adolescent Activity Log } \\
\text { (CAAL) daily for } 5 \text { days }\end{array}$ & $\begin{array}{l}\text { Significant, direct path from peer influences ( social support, modelling \& } \\
\text { norms) to boys' \& girls' PA }\end{array}$ \\
\hline $\begin{array}{l}\text { Viira \& } \\
\text { Raudsepp (2003) }\end{array}$ & $\begin{array}{l}\text { Boys }=13.01 \pm 0.2 ; \text { Girls } \\
=13.0 \pm 0.4\end{array}$ & Estonia & $\begin{array}{l}\text { Reynolds et al 1990; } 19 \text { item self } \\
\text { report questionnaire }\end{array}$ & $\begin{array}{l}\text { Friends' attitude for PA significant for PA of boys and girls; Mother's PA } \\
\text { significant for girls' PA }\end{array}$ \\
\hline $\begin{array}{l}\text { Ommundsen et } \\
\text { al. (2006) }\end{array}$ & Boys \& girls; 15 years old & Norway & $\begin{array}{l}\text { Computer-based questionnaire } \\
\text { (PEACH) }\end{array}$ & $\begin{array}{l}\text { Teachers' \& peers' social support significant for teens' school PA and LTPA. } \\
\text { Perceived parental support signific ant for teens' LTPA; Access to places } \\
\text { near by the home to play significant for teens' LTPA. }\end{array}$ \\
\hline $\begin{array}{l}\text { Spink et al. } \\
\text { (2006) }\end{array}$ & Boys \& girls; $15.5 \pm 1.6$ & Canada & $\begin{array}{l}\text { Modified Activity Qu estionnaire } \\
\text { for Adolescents (MAQ-A) }\end{array}$ & $\begin{array}{l}\text { Friends' PA and support were identified as correlates of PA by } 55 \% \text { of } \\
\text { participants; Parents' support identified by } 40 \% \text { of participants; Coach's } \\
\text { encouragement identified by } 30 \% \text { of participants; Proximity and availability } \\
\text { of PA spaces identified by } 44 \% \& 38 \% \text { of the sample, respectively. Frien ds' } \\
\text { PA was associated more with unstructured PA compared to structured PA; } \\
\text { whereas, the opposite was found for the other social correlates }\end{array}$ \\
\hline $\begin{array}{l}\text { Ward et al. } \\
\text { (2006) }\end{array}$ & $\begin{array}{l}\text { Girls; } 14.6 \pm 0.6 \text {; A frican } \\
\text { American \& Caucasian }\end{array}$ & USA & 3DPAR & $\begin{array}{l}\text { Among Caucasian girls, family support significant for PA, with active girls } \\
\text { reporting higher scores than low-active girls; Family support was not } \\
\text { associated with activity status among girls classified as at risk or } \\
\text { overweight; Home equipment significant for African American girls' PA }\end{array}$ \\
\hline $\begin{array}{l}\text { Loucaides et al. } \\
\text { (2007) }\end{array}$ & $\begin{array}{l}\text { Boys \& girls; } 15.6 \pm 1.3 \\
\text { years old; Urban \& rural }\end{array}$ & Canada & $\begin{array}{l}\text { Godin \& Shephard L eisure-Time } \\
\text { Ex ercise Questionnaire }\end{array}$ & $\begin{array}{l}\text { Friends' and family members' PA significant for PA of teens in urban and } \\
\text { rural settings }\end{array}$ \\
\hline $\begin{array}{l}\text { Haug et al. } \\
\text { (2008) }\end{array}$ & Boys \& girls; 13 years old & Norway & $\begin{array}{l}\text { One self-report item from the } \\
\text { HBSC survey }\end{array}$ & $\begin{array}{l}\text { Schools with many facilities, open fields, outdoor obstacle course, } \\
\text { playground equipment, and a room with cardio and weightlifting equipment } \\
\text { significant for PA during recess }\end{array}$ \\
\hline $\begin{array}{l}\text { McMinn et al. } \\
(2008)\end{array}$ & $\begin{array}{l}\text { Boys } \& \text { girls; grade } 9(14- \\
16 \text { years old) }\end{array}$ & Denmark & Accelerometer & $\begin{array}{l}\text { No association between peer or parental support and te ens' PA nor between } \\
\text { parental PA and teens' PA }\end{array}$ \\
\hline Loucaides (2009) & $\begin{array}{l}\text { boys and girls; grades } 78 \\
\& 9\end{array}$ & Cyprus & 5 item physical activity index & $\begin{array}{l}\text { Significant correlations between teens PA and parental PA' parental } \\
\text { encouragement, friend support, and availability of spaces to be physically } \\
\text { active }\end{array}$ \\
\hline $\begin{array}{l}\text { Deforche et al. } \\
\text { (2010) }\end{array}$ & Boys; $17.4 \pm 0.6$ years old & Belgium & $\begin{array}{l}\text { Flemish Physical Activity } \\
\text { Questionnaire }\end{array}$ & $\begin{array}{l}\text { Friends' PA and fewer electronic devices in the bedroom were positively } \\
\text { associated with boys' leisure time sports }\end{array}$ \\
\hline $\begin{array}{l}\text { Kim \& Cardinal } \\
(2010)\end{array}$ & $\begin{array}{l}\text { Boys \& girls; } 14-19 \text { years } \\
\text { old (mean }=16.40 \pm 0.48 \text { ) }\end{array}$ & Korea & $\begin{array}{l}\text { Godin \& Shephard L eisure-Time } \\
\text { Exercise Questionnaire }\end{array}$ & $\begin{array}{l}\text { Friend \& family support had a significant direct effect on PA, but friend } \\
\text { support had a stronger relationship to PA than did family support }\end{array}$ \\
\hline $\begin{array}{l}\text { Kok Sonk et al. } \\
(2010)\end{array}$ & $\begin{array}{l}\text { Boys \& girls; mean age } \\
14.4 \pm 1.1 \text { years old }\end{array}$ & Singapore & 3DPAR & $\begin{array}{l}\text { Paren tal support significant for boys' and girls' PA; sports equipment in the } \\
\text { home significant for girls' PA }\end{array}$ \\
\hline $\begin{array}{l}\text { Mulhall et al. } \\
\text { (2011) }\end{array}$ & $\begin{array}{l}\text { Boys \& girls; 12-13 years } \\
\text { old }\end{array}$ & USA & $\begin{array}{l}7 \text { items deriv ed from CDC’s } \\
\text { Youth Risk Behavior Survey }\end{array}$ & Family involvement with fitness signific ant for teens' PA. \\
\hline $\begin{array}{l}\text { Shokrvash et al. } \\
\text { (2013) }\end{array}$ & $\begin{array}{l}\text { Boys \& girls; } 12.93 \pm 0.49 \\
\text { years old }\end{array}$ & Iran & $\begin{array}{l}\text { Modified version of the } \\
\text { Adolescent Physical Activity and } \\
\text { Recall Questionn aire-APARQ }\end{array}$ & $\begin{array}{l}\text { Family support was significant predictor of teen s PA. Specifically, low } \\
\text { perceived informational support for males and low practical and emotional } \\
\text { support for females were found to be signific ant predictors of lower level of } \\
\text { PA }\end{array}$ \\
\hline $\begin{array}{l}\text { Young et al. } \\
\text { (2014) }\end{array}$ & Girls; grade 8 \& 11 & USA & Accelerometer & $\begin{array}{l}\text { Friend social support significant for PA of 8th grade girls; Positive support } \\
\text { from boys significant for PA of 11th grade girls' MVPA; Ability to use } \\
\text { school grounds for unstructured free play during school significant for PA of } \\
\text { 8th grade girls' MVPA. }\end{array}$ \\
\hline
\end{tabular}

\section{*3/7DPAR: 3/7 day physical activity recall; LTPA: leisure-time physical activity}

participants identified parents' support as a correlate of PA which is supported by the results of Ommundsen, Klasson-Heggebo, and Anderssen (2006). Regarding modelling, some found positive significant associations for family members' PA and teens PA (Loucaides, 2009; Loucaides, Plotnikoff, \& Bercovitz, 2007; Mulhall, Reis, \& Begum, 2011; Ommundsen, Klasson-Heggebo, \& Anderssen, 2006) while others found no relationship (McGuire, Hannan, Neumark-Sztainer, Cossrow, \& Story, 2002; McMinn, van Sluijs, Wedderkopp et al., 2008). The mixed results regarding parental influences are not surprising given that previous reviews have indicated positive, unclear, or no associations with adolescent PA(Edwardson \& Gorely, 2010; Gustafson \& Rhodes, 2006; Pugliese \& Tinsley, 2007; Sallis, Prochaska, \& Taylor, 2000). It is possible that these mixed results in previous reviews may be due to grouping of children and adolescents together. It is worth noting that the studies included in our review that found parental correlates to be important (Loucaides, 2009; Loucaides, Plotnikoff, \& Bercovitz, 2007; Mulhall, Reis, \& Begum, 2011; Ommundsen, Klasson-Heggebo, \& Anderssen, 2006) tended to include teens 15 years or younger while studies that found no association included older teens. Perhaps PA of younger teens is more influenced by their parents because they are more dependent on them at this age and perhaps more likely to look to them for guidance as compared to older teens who might be more impacted by their peer group. These results are consistent with those of de Vet, de Ridder, and de Wit (2011) who found that parent PA appears to be more important in childhood than adolescence.

With respect to boys, some have shown significant positive associations with parental support (Kim \& Cardinal, 2010; Kok Sonk, Loprinzi, \& Trost, 2010) and parents' encouragement for PA for Caucasian and African American boys' PA, compared to PA of Asian, Hispanic, and other race/ethnicity groups (McGuire, Hannan, NeumarkSztainer et al., 2002). Positive associations between family support and female adolescents'PA have also been found(Bungum, Pate, Dowda et al., 1999; Kim \& Cardinal, 2010; Kok Sonk, Loprinzi, \& Trost, 2010; McGuire, Hannan, Neumark-Sztainer et al., 2002; Sallis, Taylor, Dowda etal., 2002; Shokrvash, Majlessi, Montazeri etal., 2013). This relationship may not be simple, however. For instance, Ward, Dowda, Trost et al. (2006) found that family support was associated with Caucasian, but notAfrican American, girls'PA; yet, Bungum, Pate, Dowda et al. (1999) found an association between family support and PA among older African American girls'. Moreover, one study revealed that family support was not associated with PA among overweight girls (Ward, Dowda, Trost et al., 2006). Finally, pertaining to parental modelling, Virra and Raudsepp (2003) found that Mother's PA was associated with 13 year old girls' PA. 
Recommendation 1. Although, this literature does not indicate definitive positive associations between parental support or modelling and adolescents' PA, it does not point to any negative effects of this strategy. It can be expected that no one strategy will have the same effect on all teenagers, thus in line with Edwardson and Gorely (2010), we recommend that effective PA promotion programs for teens might include the promotion of PA opportunities for parents, as well as education for parents regarding the potential positive effects of their support of their adolescent's PA practices (e.g., encouragement, provision of transport to and from activities). Additional support for this recommendation stems from the ten adolescent PA promotion intervention studies that incorporated a family or parental component, most of which had a positive effect on participants' PA (Cass \& Price, 2003; Haerens, De Bourdeaudhuij, Maes, Cardon, \& Deforche, 2007; Haerens et al., 2006; Lubans, D. R., Morgan, Callister, \& Collins, 2009; Peralta, Jones, \& Okely, 2009; Ransdell, Robertson, Ornes, \& MoyerMileur, 2004; Simon et al., 2008; Young, D. R., Phillips, Yu, \& Haythornthwaite, 2006). Moreover, while the vast majority of teen PA promotion intervention studies have been school based (Bush, 2014) two systematic literature reviews found school-based interventions are effective in increasing the time adolescents are physically active during school hours, but not during leisure-time (de Meester, van Lenthe, Spittaels et al., 2009; Dobbins, De Corby, Robeson et al., 2009). Thus, extending PA promotion strategies into the home is warranted.

Recommendation 2. With respect to peer support and modelling, among the eleven studies included in this review that examined these correlates (Deforche, Van Dyck, Verloigne et al., 2010; Kim \& Cardinal, 2010; Loucaides, 2009; McMinn, van Sluijs, Wedderkopp et al., 2008; Ommundsen, Klasson-Heggebo, \& Anderssen, 2006; Raudsepp \& Viira, 2000; Sallis, Taylor, Dowda et al., 2002; Spink, Shields, Chad et al., 2006; Viira \& Raudsepp, 2003; Wu, Pender, \& Noureddine, 2003; Young, D., Saksvig, Wu et al., 2014) all but one (McMinn, van Sluijs, Wedderkopp et al., 2008) found positive associations with teens' PA, and this, regardless of their age or sex. We, therefore, recommend that future intervention studies incorporate these strategies. Indeed, some have found that self-efficacy is an important correlate of PA among teens (Sallis, Prochaska, \& Taylor, 2000) and that peer support indirectly influences teens' PA via self-efficacy (Sabiston \& Crocker, 2008; Wu, Pender, \& Noureddine, 2003). Additionally, it is important that future PA promotion intervention research assesses the effects of such peer influences on teenagers' PA as, to our knowledge, only four intervention studies have focused some attention on these influences, and none has assessed their specific effects on physical activity (Dzewaltowski et al., 2009; Lubans, D. \& Morgan, 2008; Lubans, David R. \& Sylva, 2006; Peralta, Jones, \& Okely, 2009).

\section{Physical environment}

In the literature published prior to 2000, Sallis, Prochaska, and Taylor (2000) found consistent positive associations between adolescents' PA and opportunities to exercise; yet, in their update to this review, Ferreira, van der Horst, Wendel-Vos et al. (2007) noted that availability and accessibility of exercise equipment were mostly unrelated to adolescents' PA, and in another review, Van der Horst, Paw, Twisk et al. (2007) found no association between availability of facilities and adolescents' physical activity. We found, an additional seven studies providing some evidence to indicate a positive association between teenagers' PA and availability of spaces to be physically active in the neighbourhood or on school grounds (Haug, Torsheim, \& Samdal, 2008; Loucaides, 2009; Ommundsen, Klasson-Heggebo, \& Anderssen, 2006; Spink, Shields, Chad et al., 2006; Young, D., Saksvig, Wu et al., 2014) and provision of PA equipment in the home (Kok Sonk, Loprinzi, \& Trost, 2010; Ward, Dowda, Trost et al., 2006). Regarding adolescent PA promotion intervention research, few studies have examined environmental modifications making it difficult to understand whether such strategies as increasing opportunities to be physically active can increase PA in youth (Perry, Garside, Morones et al., 2012). Nonetheless, provision of additional physical activity opportunities, such as schools providing extra physical activity equipment out of class time, or partnering with community organizations to provide additional physical activities are strategies that have met with some success (Haerens, De Bourdeaudhuij, Maes et al., 2007; Haerens, Deforche, Maes et al., 2006; Lubans, David R. \& Sylva, 2006; Webber et al., 2008).

Recommendation 3. The limited research makes it difficult for us to make any strong recommendations regarding environmental modifications. It may be that the provision of opportunities to be physically active is important but not sufficient to entice adolescents to engage in PA. Moreover, as with peer and parental support and modelling, it can be expected that such an intervention strategy may have a positive effect on PA for some teenagers in some contexts, and the literature does not point to any negative effect. Thus, we suggest that future intervention studies incorporate environmental modifications in the home and school environments and, importantly, that they study the effects of these strategies.

Recommendation 4. Regarding future research on correlations of adolescents' PA, this updated review suggests recommendations of previous reviews (Edwardson \& Gorely, 2010; Ferreira, van der Horst, Wendel-Vos et al., 2007; Sterdt, Liersch, \& Walter, 2014) still stand. Specifically, for correlates of adolescent PA weare still lacking longitudinal studies, as well as studies that use objective measures of PA, explore parental and peer support in more depth (e.g., support vs encouragement, types of support), and explore physical environmental variables (e.g. opportunities to be active). Moreover, to date, studies have explored correlates of either overall PA (Deforche, Van Dyck, Verloigne et al., 2010; Haug, Torsheim, \& Samdal, 2008; Kok Sonk, Loprinzi, \& Trost, 2010; Loucaides, 2009; McMinn, van Sluijs, Wedderkopp et al., 2008; Mulhall, Reis, \& Begum, 2011; Raudsepp \& Viira, 2000; Sallis, Prochaska, Taylor et al., 1999; Sallis, Taylor, Dowda et al., 2002; Shokrvash, Majlessi, Montazeri et al., 2013; Spink, Shields, Chad et al., 2006; Viira \& Raudsepp, 2003; Ward, Dowda, Trost et al., 2006; Wu, Pender, \& Noureddine, 2003), leisure-time PA(Kim \& Cardinal, 2010; Loucaides, Plotnikoff, \& Bercovitz, 2007; McGuire, Hannan, NeumarkSztainer et al., 2002; Ommundsen, Klasson-Heggebo, \& Anderssen, 2006), or various intensities of PA(Bungum, Pate, Dowda et al., 1999; Young, D., Saksvig, Wu et al., 2014). Clarifying any distinctions among correlates of these various types of PA may be warranted.

\section{Limitations}

We did not complete a critical appraisal of the studies we included and we acknowledge that this could be considered a limitation of this work. For instance, included studies used a variety of self-report measures, not all of which are validated (Table 1). Moreover, given study designs, the directions of the relationships reported are, for the most part, unknown. However, given our objective to shed light on what is known about modifiable correlates of teenagers' PA and given that this area has not been routinely studied, we believed it was relevant to include all studies that reported correlates of interest. Indeed, in the context of this review we are inclined to side with Pawson (2006) that «[t]here are often nuggets of wisdom in methodologically weak studies» (p.127). In addition, we did not include theses or dissertations, published abstracts or presentations, and therefore this must be considered when interpreting results.

Despite its limitations, the current paper has several strengths. First, unlike other reviews (de Vet, de Ridder, \& de Wit, 2011; Edwardson \& Gorely, 2010; Ferreira, van der Horst, Wendel-Vos et al., 2007; Sallis, Prochaska, \& Taylor, 2000; Van der Horst, Paw, Twisk et al., 2007), we highlight differences among subgroups of the adolescent population. Namely, younger and older adolescents and boys and girls. Second, whereas other reviews have addressed non-modifiable correlates together with modifiable ones (de Vet, de Ridder, \& de Wit, 2011; Ferreira, van der Horst, Wendel-Vos et al., 2007; Sallis, Prochaska, \& Taylor, 2000; Van der Horst, Paw, Twisk et al., 2007), we concentrate only on 
modifiable ones. As such, we have been able to provide recommendations to help researchers and practitioners design effective interventions to increase PA among teens. Indeed, our findings lead us to suggest that future adolescent PA promotion research may consider designing interventions to modify teen's social and physical environments. For instance, interventions may focus on promoting PA to parents such that they may model the behavior, or promote the importance of parents and peers being supportive of adolescents' PA. In turn, such interventions may help to increase PA among teenagers.

\section{References}

Beets, M. W., Vogel, R., Forlaw, l., Pitetti, K. H., \& Cardinal, B. J. (2006). Social support and youth physical activity: the role of provider and type. American Journal of Health Behavior, 30(3), 278-289. doi: http://dx.doi.org/10.5993/AJHB.30.3.6

Biddle, S. J. H., Atkin, A. J., Cavill, N., \& Foster, C. (2011). Correlates of physical activity in youth: a review of quantitative systematic reviews. International Review of Sport and Exercise Psychology, 4(1), 25-49. doi: 10.1080/1750984x.2010.548528

Bungum, T., Pate, R., Dowda, M., \& Vincent, M. (1999). Correlates of physical activity among African-American and Caucasian female adolescents. American Journal of Health Behavior, 23(1), 25-31.

Bush, P. L. (2014). Building on a YMCA's health and physical activity promption capacities: a case study of a researcher-organization partnership to optimize adolescent programming. (Doctor of Philosophy), McGill University, Montreal, Quebec. Retrieved from http://digitool.Library.McGill.CA:80/R/-?func=dbin-jumpfull\&object_id=122984\&silo_library=GEN01

Cass, Y., \& Price, P. (2003). Moorefit—increasing physical activity in adolescent girls using the Health Promoting Schools framework. Health Promotion Journal of Australia, 14, 159-164.

Colley, R. C., Garriguet, D., Janssen, I., Craig, C. L., Clarke, J., \& Tremblay, M. S. (2012). Physical activity of Canadian children and youth: accelerometer results from the 2007 to 2009 Canadian Health Measures Survey. Health Reports, 22(2).

Crutzen, R. (2010). Adding effect sizes to a systematic review on interventions for promoting physical activity among European teenagers. International Journal of Behavioral Nutrition and Physical Activity, 7(29). http://www.ijbnpa.org/content/pdf/1479-5868-729.pdf doi:10.1186/1479-5868-7-29

de Meester, F., van Lenthe, F. J., Spittaels, H., Lien, N., \& De Bourdeaudhuij, I. (2009). Interventions for promoting physical activity among European teenagers: a systematic review. International Journal of Behavioral Nutrition and Physical Activity, 6(82). http://www.ijbnpa.org/content/pdf/1479-5868-6-82.pdf doi:10.1186/1479-5868-6-82

de Vet, E., de Ridder, D. T. D., \& de Wit, J. B. F. (2011). Environmental correlates of physical activity and dietary behaviours among young people: a systematic review of reviews. Obesity Reviews, 12(501), e130-e142. doi: 10.1111/j.1467-789X.2010.00784.x

Deforche, B., Van Dyck, D., Verloigne, M., \& De Bourdeaudhuij, I. (2010). Perceived social and physical environmental correlates of physical activity in older adolescents and the moderating effect of self-efficacy. Preventive Medicine, 50, S24-S29. doi: 10.1016/ j.ypmed.2009.08.017

Dobbins, M., De Corby, K., Robeson, P., Husson, H., \& Tirilis, D. (2009). School-based physical activity programs for promoting physical activity and fitness in children and adolescents aged 6-18 Cochrane Database of Systematic Reviews(Issue 1. Art No.:CD007651). doi: 10.1002/14651858.CD007651

Dzewaltowski, D.A., Estabrooks, P. A., Welk, G., Hill, J., Milliken, G., Karteroliotis, K., \& Johnston, J. A. (2009). Healthy Youth Places: a randomized controlled trial to determine the effectiveness of facilitating adult and youth leaders to promote physical activity and fruit and vegetable consumption in middle schools. Health
Education \& Behavior, 36(3), 583-600. doi: 10.1177/ 1090198108314619

Edwardson, C. L., \& Gorely, T. (2010). Parental influences on different types and intensities of physical activity in youth: a systematic review. Psychology of Sport and Exercise, 11(6), 522-535. doi: http://dx.doi.org/10.1016/j.psychsport.2010.05.001

Ekelund, U., Tomkinson, G. R., \& Armstrong, N. (2011). What proportion of youth are physically active? Measurement issues, levels and recent time trends. British Journal of Sports Medicine, 45(11), 859-865.

Ferreira, I., van der Horst, K., Wendel-Vos, W., Kremers, S., van Lenthe, F. J., \& Brug, J. (2007). Environmental correlates of physical activity in youth - a review and update. Obesity Reviews, 8(2), 129-154. doi: 10.1111/j.1467-789X.2006.00264.x

Fitzgerald, A., Fitzgerald, N., \& Aherne, C. (2012). Do peers matter? A review of peer and/or friends' influence on physical activity among American adolescents. Journal of Adolescence, 35(4), 941-958. doi: http://dx.doi.org/10.1016/j.adolescence.2012.01.002

Gustafson, S. L., \& Rhodes, R. E. (2006). Parental correlates of physical activity in children and early adolescents. Sports Medicine, 36(1), 79-97. doi: 10.2165/00007256-200636010-00006

Haerens, L., De Bourdeaudhuij, I., Maes, L., Cardon, G., \& Deforche, B. (2007). School-based randomized controlled trial of a physical activity intervention among adolescents. The Journal of adolescent health : official publication of the Society for Adolescent Medicine, 40(3), 258-265. doi: 10.1016/j.jadohealth.2006.09.028

Haerens, L., Deforche, B., Maes, L., Stevens, V., Cardon, G., \& De Bourdeaudhuij, I. (2006). Body mass effects of a physical activity and healthy food intervention in middle schools. Obesity, 14(5), 847-854. doi: 10.1038/oby.2006.98

Haug, E., Torsheim, T., \& Samdal, O. (2008). Physical environmental characteristics and individual interests as correlates of physical activity in Norwegian secondary schools: the health behaviour in school-aged children study. International Journal of Behavioral Nutrition and Physical Activity, 5. doi: 10.1186/1479-5868-5-47

Kim, Y.H., \& Cardinal, B. J. (2010). Psychosocial correlates of Korean adolescents' physical activity behavior. Journal of Exercise Science \& Fitness, 8(2), 97-104. doi: 10.1016/s1728-869x(10)60015-9

Kok Sonk, L., Loprinzi, P. D., \& Trost, S. G. (2010). Determinants of Physical Activity in Singaporean Adolescents. International Journal of Behavioral Medicine, 17(4), 279-286.

Landis, J. R., \& Koch, G. G. (1977). The measurement of observer agreement for categorical data. Biometrics, 33(1), 159-174.

Loucaides, C. A. (2009). School location and gender differences in personal, social, and environmental correlates of physical activity in Cypriot middle school children. Journal of Physical Activity \& Health, 6(6), 722-730.

Loucaides, C.A., Plotnikoff, R. C., \& Bercovitz, K. (2007). Differences in the correlates of physical activity between urban and rural Canadian youth. Journal of School Health, 77(4), 164-170. doi: 10.1111/j.1746-1561.2007.00187.x

Lubans, D., \& Morgan, P. (2008). Evaluation of an extra-curricular school sport programme promoting lifestyle and lifetime activity for adolescents. Journal of Sports Sciences, 26(5), 519-529. doi: 10.1080/02640410701624549

Lubans, D. R., Morgan, P. J., Callister, R., \& Collins, C. E. (2009). Effects of integrating pedometers, parental materials, and e-mail support within an extracurricular school sport intervention. Journal of Adolescent Health, 44(2), 176-183. doi: 10.1016/ j.jadohealth.2008.06.020

Lubans, D. R., \& Sylva, K. (2006). Controlled evaluation of a physical activity intervention for senior school students: effects of the lifetime activity program. Journal of Sport \& Exercise Psychology, 28, 252268.

McGuire, M. T., Hannan, P. J., Neumark-Sztainer, D., Cossrow, N. H. F., \& Story, M. (2002). Parental correlates of physical activity in a 
racially/ethnically diverse adolescent sample. Journal of Adolescent Health, 30(4), 253-261. doi: 10.1016/s1054-139x(01)00392-5

McMinn, A. M., van Sluijs, E. M. F., Wedderkopp, N., Froberg, K., \& Griffin, S. J. (2008). Sociocultural correlates of physical activity in children and adolescents: findings from the Danish arm of the European Youth Heart Study. Pediatric Exercise Science, 20(3), 319-332.

Moher D, Liberati A, Tetzlaff J, Altman DG, \& The PRISMA Group. (2009). Preferred reporting items for systematic reviews and metaAnalyses: the PRISMA Statement. Plos Medicine, 6(66).

Mulhall, P., Reis, J., \& Begum, S. (2011). Early adolescent participation in physical activity: correlates with individual and family characteristics. Journal of Physical Activity \& Health, 8(2), 244252.

National Institute for Health and Care Excellence. (2009). Promoting physical activity for children and young people. (NICE publichealth guidance 17). London: National Institute for Health and Care Excellence Retrieved from www.nice.org.uk/guidance/ph17.

Ommundsen, Y., Klasson-Heggebo, L., \& Anderssen, S. A. (2006). Psycho-social and environmental correlates of location-specific physical activity among 9- and 15- year-old Norwegian boys and girls: the European Youth Heart Study. The international journal of behavioral nutrition and physical activity, 3, 32-32. doi: 10.1186/ 1479-5868-3-32

Pawson, R. (2006). Digging for Nuggets: How ‘Bad’ Research Can Yield 'Good' Evidence. International Journal of Social Research Methodology, 9(2), 127-142. doi: 10.1080/13645570600595314

Peralta, L. R., Jones, R. A., \& Okely, A. D. (2009). Promoting healthy lifestyles among adolescent boys: the Fitness Improvement and Lifestyle Awareness program RCT. Preventive Medicine, 48(6), 537-542. doi: 10.1016/j.ypmed.2009.04.007

Perry, C. K., Garside, H., Morones, S., \& Hayman, L. L. (2012). Physical activity interventions for adolescents: an ecological perspective. Journal of Primary Prevention, 33(2-3), 111-135. doi: 10.1007/s10935-012-0270-3

Pugliese, J., \& Tinsley, B. (2007). Parental socialization of child and adolescent physical activity: a meta-analysis. Journal of Family Psychology, 21(3), 331-343. doi: 10.1037/0893-3200.21.3.331

Ransdell, L. B., Robertson, L., Ornes, L., \& Moyer-Mileur, L. (2004). Generations Exercising Together to Improve Fitness (GET FIT): a pilot study designed to increase physical activity and improve health-related fitness in three generations of women. Women Health, 40(3), 77-94

Raudsepp, L., \& Viira, R. (2000). Sociocultural correlates of physical activity in adolescents. Pediatric Exercise Science, 12(1), 51-60.

Sabiston, C. M., \& Crocker, P. R. E. (2008). Exploring self-perceptions and social influences as correlates of adolescent leisure-time physical activity. Journal of Sport \& Exercise Psychology, 30(1), 3-22.

Sallis, J. F., Prochaska, J. J., \& Taylor, W. C. (2000). A review of correlates of physical activity of children and adolescents. Medicine \& Science in Sports \& Exercise, 32(5), 963-975.

Sallis, J. F., Prochaska, J. J., Taylor, W. C., Hill, J. O., \& Geraci, J. C. (1999). Correlates of physical activity in a national sample of girls and boys in Grades 4 through 12. Health Psychology, 18(4), 410415. doi: 10.1037/0278-6133.18.4.410

Sallis, J. F., Taylor, W. C., Dowda, M., Freedson, P. S., \& Pate, R. R. (2002). Correlates of vigorous physical activity for children in grades 1 through 12: comparing parent-reported and objectively measured physical activity. Pediatric Exercise Science, 14(1), 3044.

Shokrvash, B., Majlessi, F., Montazeri, A., Nedjat, S., Rahimi, A., Djazayeri, A., \& Shojaeezadeh, D. (2013). Correlates of physical activity in adolescence: a study from a developing country. Global health action, 6, 20327-20327. doi: 10.3402/gha.v6i0.20327

Silva, P., Lott, R., Wickrama, K. A. S., Mota, J., \& Welk, G. (2012). Psychosocial correlates of physical activity in two cultural contexts: different pathways? Journal of Physical Activity \& Health, 9(4), 581-593.

Simon, C., Schweitzer, B., Oujaa, M., Wagner, A., Arveiler, D., Triby, E., Copin, N., Blanc, S., \& Platat, C. (2008). Successful overweight prevention in adolescents by increasing physical activity: a 4-year randomized controlled intervention. International Journal of Obesity, 32(10), 1489-1498. doi: 10.1038/ijo.2008.99

Spink, K. S., Shields, C. A., Chad, K., Odnokon, P., Muhajarine, N., \& Humbert, L. (2006). Correlates of structured and unstructured activity among sufficiently active youth and adolescents: as new approach to understanding physical activity. Pediatric Exercise Science, 18(2), 203-215.

Sterdt, E., Liersch, S., \& Walter, U. (2014). Correlates of physical activity of children and adolescents: a systematic review of reviews. Health Education Journal, 73(1), 72-89. doi: 10.1177/ 0017896912469578

Van der Horst, K., Paw, M. J. C. A., Twisk, J. W. R., \& Van Mechelen, W. (2007). A brief review on correlates of physical activity and sedentariness in youth. Medicine and Science in Sports and Exercise, 39(8), 1241-1250. doi: 10.1249/mss.0b013e318059bf35

van Sluijs, E. M. F., McMinn, A. M., \& Griffin, S. J.(2008). Effectiveness of interventions to promote physical activity in children and adolescents: systematic review of controlled trials. British Journal of Sports Medicine, 42(8), 653-657. doi: 10.1136/ bmj.39320.843947.BE

Viira, R., \& Raudsepp, L. (2003). Psychosocial correlates of physical activity among seven through eight grades. Journal of Human Movement Studies, 44(6), 501-517.

Ward, D. S., Dowda, M., Trost, S. G., Felton, G. M., Dishman, R. K., \& Pate, R. R. (2006). Physical activity correlates in adolescent girls who differ by weight status. Obesity, 14(1), 97-105. doi: 10.1038/ oby.2006.12

Webber, L. S., Catellier, D. J., Lytle, L. A., Murray, D. M., Pratt, C. A., Young, D. R., Elder, J. P., Lohman, T. G., Stevens, J., Jobe, J. B., \& Pate, R. R. (2008). Promoting physical activity in middle school girls: trial of activity for adolescent girls. American Journal of Preventive Medicine, 34(3), 173-184. doi: 10.1016/ j.amepre.2007.11.018

World Health Organization. (2004). Global strategy on diet, physical activity and health. Geneva, Switzerland:World Health Organization (WHO).

Wu, S.-Y., Pender, N., \& Noureddine, S. (2003). Gender differences in the psychosocial and cognitive correlates of physical activity among Taiwanese adolescents: a structural equation modeling approach. International Journal of Behavioral Medicine, 10(2), 93-105.

Young, D., Saksvig, B. I., Wu, T. T., Zook, K., Li, X., Champaloux, S., Grieser, M., Lee, S., \& Treuth, M. S. (2014). Multilevel correlates of physical activity for early, mid, and late adolescent girls. Journal of PhysicalActivity \& Health, 11(5), 950-960. doi: 10.1123/jpah.20120192

Young, D. R., Phillips, J. A., Yu, T., \& Haythornthwaite, J. A. (2006). Effects of a life skills intervention for increasing physical activity in adolescent girls. Archives of Pediatrics \& Adolescent Medicine, 160(12), 1255-1261. doi: 10.1001/archpedi.160.12.1255

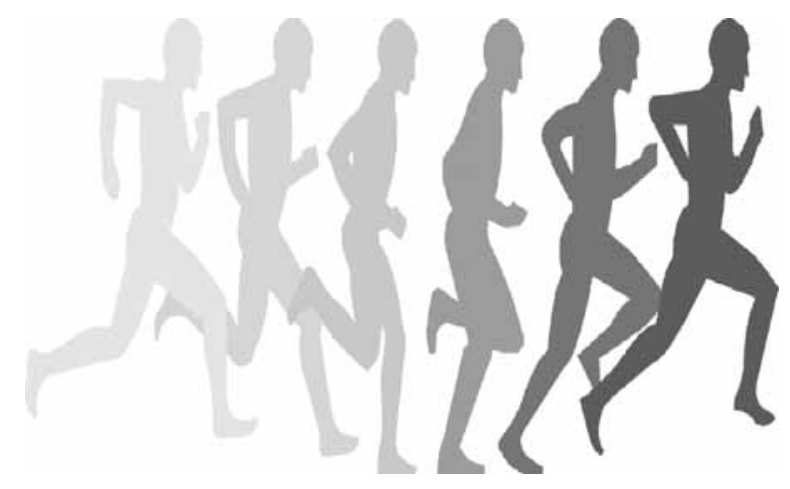

